\title{
Research on Tax Issues of Shared Economic Business Model
}

\author{
Zhijian Yu \\ Information Management and Information System, School \\ of Economics and Management \\ Beijing University of Posts and Telecommunications \\ Beijing, China
}

\author{
Hefei Bai \\ Department of Accounting, School of Economics and \\ Management \\ Beijing University of Posts and Telecommunications
} Beijing, China

\begin{abstract}
With the enlightenment and guidance of Uber and Airbnb, the shared economic rises rapidly in China. And since Shared economic can share resource, reduce congestion, protect environment, improve the employment, it become popular with people. But there are problems such as unfair competition with traditional economy, tax evasion, lack of supervision, which was criticized. In the context of the implementation of the "Internet $+"$ strategy, to promote the network about car rental, and actively promote the standardization of new forms of online rental housing development is the only way to develop the shared economy. This paper analyzes the necessity and feasibility of tax sharing economy business model, from the perspective of tax sharing business model puts forward to strengthen economic supervision and management advice, in order to promote the healthy and orderly development of the shared economy, increase social welfare.
\end{abstract}

Keywords-shared economy, transaction platform, tax object, tax jurisdiction, tax registration

Sharing economic concept proposed in 1978 by American sociology professor Marcus Felson and Joe L. Spaeth, along with the development of Internet technology, the Third-party trading platform, developed rapidly in recent years. The sharing economy, through the Internet to break the boundaries of time and space, solve the problem of resource waste caused by asymmetric information between supply and demand, improve resource utilization efficiency. For example, as soon as Uber and Airbnb entered the rental market, the housing rental market was sought after highly, which causes shortage immediately. [1] On March 2015, Premier Li Keqiang put forward the "Internet + " action plan in the government work report, and in July the action guidance, emphasized the shared economic development network about car rental, rent online and other new formats. The development of a shared economy, not only can expand employment, increase income, but also conducive to promoting social vertical mobility and fairness and justice, and promote public entrepreneurship, innovation. But as a new thing, there are some problems, such as lack of supervision, tax evasion and unfair competition with the traditional business model. Therefore, it is the only way for the healthy and orderly development of the shared economic industry to strengthen the tax administration of the shared economy and pay taxes according to the tax law.

\section{A SHAREd ECONOMY Business MODEL}

\section{A. The meaning and characteristics of the shared economic business model}

Shared economy, also known as the sharing of the economy, is created by the third-party based on the information technology trading platform, the realization of idle resources exchanging between individual and service business model. The sharing of economic development is to transfer the use of idle resources to supply the basis of the right, to share platform for media linked to the supply and demand sides. As a result, the demand side is to lower the cost of obtaining the right to the use of resources, while the supply side transfers the right of use of resources to obtain the corresponding reward.

Sharing economy business models uses idle resources, improves the efficiency of the use of resources, makes the best use of it, and mainly has the following features:

1) Temporary separation of unused resources and ownership.

Temporarily idle resources are the material basis of shared economy. Through the third-party trading platform for the exchange of information, the owner will lend or lease idle resources to the users, the ownership and use of temporary separation to achieve the maximum utilization of goods and benefits and achieve the integration of resources among individuals. Under the traditional economic model, the owners and users of resources to achieve the exchange of information must be through an intermediary. That is to say that it is through the "owner - medium - users". If the amount of information exchange is limited, it will produce the corresponding transaction cost. Hence there will be a waste of idle phenomenon. The core of a shared economy is to use, not to hold, to make full use of idle resources by renting or borrowing rather than buying a commodity or service.

2) The Internet as the bridge of the third-party trading platform.

With the development of "the cloud to move things", thirdparty Internet trading platform for individual information transfer between bridge and exchange, the sharing economy from the ideal into reality. People can publish all kinds of idle resource information through the third-party trading platform, such as through "Airbnb”, "piggy short rent” to release car 
rental information, release travel demand information through Uber, and requesters release demand information through the trading platform. Third-party trading platform will be a large number of suppliers and demanders together, use the large data analysis and intelligent mobile terminal matching to realize supply and demand docking, information exchange, resource sharing. The traditional business model is gradually replaced by the shared mode, eliminating the information gap between supply and demand sides, greatly reducing the transaction costs. At the same time, payment methods on the Internet platform and the evaluation system are becoming more and more mature, and the two sides can trade quickly establish a transaction understanding, trust and contract relations, and accelerate the development of shared economy.

3) To achieve direct resource sharing among individuals.

"I'm yours", which explains the core value of shared economy. That is sharing. The traditional leasing mode can achieve the exchange of goods and services, such as housing, car rental, etc., but its efficiency is low, unable to meet the huge demand and supply. In the shared economy, through the third-party trading platform, it can be a large number of resources through text, pictures vividly published on the Internet, in order that the users can find their own resources through the platform. In the shared economy, the supply and demand sides are linked together to achieve the direct resource sharing between individuals.

\section{THE NECESSITY AND FEASIBILITY OF TAX SHARING BUSINESS MODEL}

\section{A. The necessity of tax sharing business model}

At present, whether the business model of the shared economy is taxed or not, the tax law is not clearly defined, and there is a lack of corresponding enforcement basis. This increases the difficulty of taxing the business model of the shared economy, and even causes the illusion of non-taxation. In fact, in accordance with the provisions of the tax law, as long as the transaction behavior or income is not in the free scope of the tax law, the tax is on liability. Therefore, the tax sharing business model is conducive to the realization of the principle of tax fairness, and promote the development of trade norms under the shared economy and reduce tax losses.

1) The need to maintain the fair principle of taxation.

Sharing economy business model compared with the traditional economic model, based on the Internet information platform for technical support, can be more efficient in both supply and demand, but in essence, there is no difference with the traditional taxi industry. The hotel industry is providing transportation, accommodation services. As a result, it is necessary to maintain the fairness of the tax revenue, which is conducive to the fair competition between the shared economic model and the traditional economic model.

2) To promote the development of the business model of shared economy.

The sharing economy is playing an increasingly important role in improving the efficiency of resource utilization, reducing traffic congestion and protecting the environment, and has become an important part of people's lives. However, due to the low threshold of the industry, just putting an application to the operating platform after a simple certification can become the driver on the platform, or the landlord. Such as private car drivers who want to become the main Uber, only need to use intelligent mobile phone to download Uber driver, finish the registration of personal information, and upload the photo of vehicle driving license and your vehicle and yourself in 5 minutes, and then carry out the driver training courses, fill the bank card. This kind of operation is simple, so the market threshold is low, which will bring convenience to people, but also be faced with the safety of workers, consumers and other issues, which is not conducive to the long-term development of the shared economy. It is helpful to create a safe, fair and orderly trading platform, regulate trade rules and order in order to protect the legitimate rights and interests of workers and consumers.

\section{B. The feasibility of tax sharing business model}

1) The trading market has begun to take shape.

Uber and Airbnb's business model is to adapt to the new economic model of the times, the effective allocation of resources to meet the needs of society, the rapid development in China, whose trading market has begun to take shape. According to the report shows that in the past two years, the average annual growth rate of employees in the shared economy was more than $50 \%$, and the total number of people involved in the sharing of economic activity has more than 500 million people.

2) The payment of the third-party payment may become possible.

Third-party payment platform is an important basis for the development of shared economy. Many shared economic business models use Alipay, WeChat and other three party payments. According to Analysys thinking tank released "China third-party mobile payment market quarterly monitoring report 2015 second quarter" data, in the second quarter of 2015, Chinese third-party mobile payment market transactions amounted to 34746 yuan, an increase of $22.81 \%$. In the transaction, the existence of the Third-party payment platform makes it possible to withhold and remit the tax collection and administration, which is helpful to reduce the collection cost.

\section{3) Foreign practice provides a practical reference.}

Shared economic business model from the birth of a dispute, which is closely related to the existence of regulatory gaps, suspected of tax evasion and other issues. Whether it is to provide travel services like Uber, or provide accommodation services like Airbnb, operating income should be taxed in accordance with the law. Such as New York from the hotel operator or the registration of the hotel room to receive the rent or the cost of the landlord to rent per room per day or $6 \%$ of the cost of hotel tax collection. In March 2014, Airbnb began to levy an $11.5 \%$ tax on the hotel reservation in Portland, Oregon, and from the year of October, on the site of the "temporary occupancy tax" to short-term tenants to levy a hotel tax of $14 \%$. [2] Australian tax bureau also announced that it will be forced to provide carpooling services through the Uber platform for business registration, and pay $10 \%$ of the total revenue as a commodity and service tax. These provide a practical reference 
for the collection and management of China's shared economic and business model.

\section{THE SHARING OF ECONOMIC BUSINESS MODEL FACING THE TAX PROBLEM}

\section{A. Tax system confusion}

The subject of tax payment, the tax object and the tax rate are the three core elements of the tax system, and it is the most important problem that how to accurately determine the three essential factors in the sharing of the economic business model.

1) It is difficult to determine the subject of tax payment.

Sharing economy business model which is attach resources supply and demand sides together, is funded by the resource demand through the third-party payment platform to return to the network trading platform, and the net income after the rest platform will be into the resource provider account.

From the point of view of the flow of funds, the third-party payment platform, network trading platform and resource providers are the main tax, bear the corresponding obligations. However, the tax system of our country does not have specific provisions on the subject of tax in the business model of shared economy. In general, the tax authorities are through the tax registration of taxpayers for tax regulation. However, private car owners, landlords, simply by the platform for a simple application for registration, are not to the traffic management department, the property management department for the record, and no corresponding tax registration. In addition, the diversity and complexity of the business forms of the shared economy bring difficulties to the determination of the subject of tax payment. [3]

\section{2) The boundary of tax object is blurred.}

The object of taxation is to solve the problem of tax collection. The object of Taxation reflects the scope and boundary of Taxation, and it is the main mark of distinguishing different kinds of taxes. However, in the business model of shared economy, the boundary of tax object is vague and difficult to distinguish.

\section{3) Tax rate uncertainty.}

The business model of shared economy does not have an impact on the tax rate, but the tax rate varies with the tax object. In the reform of value-added tax business tax, which defined clear boundaries between transportation service and modern service industry, it provides transportation services value-added tax rate of $11 \%$, and set modern service industry at the rate of $6 \%$. Sharing economy business model network platform usually use the company of science and technology or network information technology company name in registration. Then whether the network platform provides transportation services or modern service industry has become the focus of debate on the tax. At present, the tax law has not clearly defined the object of Taxation and its tax rate, the lack of appropriate basis for the tax, resulting in the sharing of economic business model tax rate uncertainty.

\section{B. Challenges of tax collection and management}

1) Paperless transactions bring difficulties to tax collection and administration.

In the traditional trading activities, the invoice as a transaction document, can record the transaction, the transaction content, amount, date and other content, which is used to prove that the transaction occurs, clear responsibility and legal effect. But in the sharing economy business model, both sides of the transaction through the network trading platform, its orders, contracts, payment records are transferred in the form of electronic data. The network platform is not active and customers do not invoice invoices for problems coexist, so the whole process is paperless trading, lack of evidence.

2) The current tax jurisdiction is facing challenges.

Shared economic business model is distributed in all walks of life, all over the country, also involves the issue of tax jurisdiction. Sharing economy business model can provide technical guidance, consulting, information services through the network platform. Institutions have been virtualized in the virtual network. Whether through institutions, service place or consumption place are more difficult to determine who owns the tax jurisdiction.

\section{TO STRENGTHEN THE SHARING OF ECONOMIC BusinesS MODEL TAX TREATMENT RECOMMENDATIONS}

Shared economic business model as a new industry, new formats, both through preferential tax policies to support the development and expansion of the shared economic platform, but also can't be separated from the rule of law. All kinds of problems brought by economic norms and shared governance, into the taxation scope, social responsibility, pay taxes according to the law, will be conducive to the sharing of economic business model standardization, promote the integration of the coordinated development of new economy and traditional economy. [4]

\section{A. Improve the existing laws and regulations to promote the development of shared economy}

Sharing economy business model survived in the suspicion of illegal tax evasion and the praise in promoting the effective utilization of resources, and meeting the needs of the public. In order to guide the business model to make best use of the advantages and bypass the disadvantages, its business activities should be limited by laws and regulations.

1) To develop an industry standard for a shared economic business model and to clarify its legal status.

In the operation of the shared economy business model, it has been questioned, and even that it has the problem of illegal operation, which is related to the lack of relevant laws and regulations. Network booking car is not in accordance with the traditional taxi management approach for management, but government should formulate the corresponding industry standards, responsibility and duty to clear network platform personnel standards and requirements on joining the platform vehicle. Only by obtaining the appropriate permission can drivers engage in the corresponding business activities. It can 
both ensure the legitimate operation of practitioners, but also meet the needs of people travel to protect their consumer rights.

2) Determine the nature of the trading platform.

It is directly related to the scope of business and the application of tax revenue to clear the nature of the business platform. Shared economy business model through the network trading platform, to achieve the sharing of resources between individuals, then, at least three parties involved in the sharing economy, namely, supply side, demand side and the Thirdparty trading platform. If the user calls a car with Uber, Uber trading platform is engaged in the transportation industry or the modern service industry, which is directly related to the application of tax rates. At present, from the name of limousine service companies, they are named science and technology limited company or network information technology company, which is approved by the project management on technology development, technology consulting, technology services, technology promotion, basic software services, software services, software development, enterprise management consulting, not including transportation service. Therefore, it is proposed to clear the nature of the service platform of modern service industry, according to the modern service industry to pay the corresponding value-added tax and income tax.

\section{3) Define the tax obligation of employees.}

In a shared economy business model, it is usually a natural person who will temporarily idle resources for sharing, thereby gaining benefits. Such as personal by Airbnb will own the right to use the house, transferring out individuals to provide education and training, information consulting, business guidance and other services through the network platform, to obtain the corresponding income should pay individual income tax. While the drivers engaged in the service is also a tax liability, whose identity directly affects the driver's tax issues.

\section{4) To determine preferential tax policies.}

The sharing economy is still in its early stages, and its spawned business model is revolutionary, and has enormous potential benefits to the public. Formulating reasonable rules, clearing the direction of development and framework of fairness and the traditional economic model of tax burden can promote the healthy and orderly development of the sharing economy; enhance the welfare of society as a whole. It is suggested that the state should formulate appropriate tax preferential policies to promote the development of the business model of shared economy through the design of the starting point and the exemption amount.

\section{A. Tax registration, strengthen supervision}

With the development of "the cloud to move things", to determine whether the location of tax has been difficult to adapt to the needs of the development of business models. Tax registration is the premise of effective tax collection and management, the establishment of a shared economic business model of tax registration system, the transaction platform, practitioners into the scope of tax regulation. China is about to implement a unified system of taxpayer identification number, the establishment of a national taxpayer files. Network platform, employees according to their own unique identification number to the individual resident or business location of the tax department for tax registration, the transaction will be included in the tax department management. Tax authorities can provide tax registration is a prerequisite for the sharing of the economy. Only after the tax registration can they join the network platform and obtain income through the Third-party payment.

\section{B. Strengthen the management of network payment platform, the implementation of withholding tax}

Monitoring the capital flow is the key of tax collection and management. With the development of electronic technology, online payment popularization, security has been improved, so that the network payment platform as a shared economy tax withholding party as possible, which will improve the efficiency of tax administration, and to strengthen the supervision of tax, reduce the tax cost.

\section{Strengthen the coordination of departments, the establishment of tax source management coordination mechanism}

1) To establish a unified government information platform. Establishment led by the government, big data in public security, transportation, insurance, tourism, taxation and other departments of the information exchange platform, can realize information sharing. Tax authorities in the tax collection and management system through the information system to find the vehicle operating platform and the taxpayer's information, to carry out comparative analysis, standardize tax collection and management. At the same time, the government should establish the national and local tax departments and the information communication mechanism of the above departments, to carry out regular exchanges, through the information provided by the departments to find clues to the tax evasion of taxpayers. Belong to the state and local tax co management of taxpayers, state and local tax departments should share information resources, with the tax collection and management work.

\section{2) Increase the intensity of tax subsidies.}

The national tax administration and the Ministry of public security, the Ministry of transportation and Tourism Bureau shall negotiate the introduction of tax related normative documents, the relevant departments of the specific tax obligations, strengthen coordination, regularly carry out joint law enforcement inspection, thorough investigation of tax evasion.

\section{REFERENCES}

[1] Yan Jingyu: "Uber (excellent step) to inspire and lead the thinking of global shared economic development", "shopping mall modernization" in 2015, the nineteenth phase.

[2] Jeremy Rifkin: "the trend of networking and sharing economy", "enterprise research" in 2015 second.

[3] Brilliant yellow: "China's C2C e-commerce tax management issues, "Tax research" in 2015 third.

[4] Lin Yongqing: "the rise of the shared economy and the future of "public finance", " Chinese and foreign management "in 2015 second 